\title{
ENDOPHYTIC FUNGI ASSOCIATED WITH ROOTS OF EPIPHYTIC ORCHIDS IN TWO ANDEAN FORESTS IN SOUTHERN ECUADOR AND THEIR ROLE IN GERMINATION
}

\author{
Jazmin M. Salazar ${ }^{1}$, Marisol Pomavilla ${ }^{2}$, Anne T. Pollard ${ }^{3}$, Eduardo J. Chica ${ }^{2}$ \\ $\&$ Denisse F. PeÑA 2,4
${ }^{1}$ Centro de Investigación, Innovación y Transferencia de Tecnología, Universidad Católica de Cuenca, Vía a Bibí, Ricaurte, Cuenca, Ecuador
${ }^{2}$ Facultad de Ciencias Agropecuarias, Universidad de Cuenca, Av. 12 de Octubre y Diego de Tapia, Cuenca, Ecuador
${ }^{3}$ Department of Soil \& Water Systems, University of Idaho, 875 Perimeter Drive MS 2340, Moscow, ID 83844-2340, U.S.A.
${ }^{4}$ Author for correspondence: denisse.pena@ucuenca.edu.ec

\begin{abstract}
Orchids are known to establish complex relationships with endophytic fungi throughout their life cycle, and particularly during germination of their reserves-deprived seeds. Characterizing generalist or specialist interactions between orchids and associated fungi is key to supporting orchid conservation efforts. Here, endophytic fungi associated with roots of epiphytic orchids were studied in two montane Andean forests in Southern Ecuador. Orchid root samples were collected from ten $\sim 500 \mathrm{~m}^{2}$ plots distributed between two neighboring forests. Endophytic fungi associated with these roots were then isolated, cultured, and identified by sequencing of rDNA markers. In total, 52 pure isolates were recovered from the roots of 10 orchid species. These isolates were classified into nine taxonomic groups except for one isolate that remained unclassified. Most fungal isolates were found in roots of up to two different orchid species; however, Coprinellus radians was found in the roots of all sampled orchids. The potential of $C$. radians to promote germination of orchid seeds was tested in a separate assay using seeds from two orchid species different than those found in the experimental forest plots. Of the two C. radians isolates tested, one improved germination in the two orchids evaluated to a level about half of that observed in seeds germinated in nutrient-rich medium (Phytamax) and above the null germination observed in plates without the fungus. Together, these results revealed a generalist relationship between $C$. radians and all the studied epiphytic orchids and the potential role of this fungus as a promoter of orchid seed germination.
\end{abstract}

Resumen. Las orquídeas establecen interacciones complejas con hongos endófitos a lo largo de su ciclo de vida, particularmente durante la germinación de sus semillas limitadas de reservas de nutrientes. Caracterizar interacciones generalistas y específicas entre las orquídeas y sus hongos asociados es clave para apoyar esfuerzos para su conservación. En este trabajo se estudiaron los hongos endófitos asociados a raíces de orquídeas epífitas de dos bosques montanos del sur del Ecuador. Se colectaron raíces de orquídeas de diez parcelas de $\sim 500 \mathrm{~m}^{2}$ distribuidas en dos bosques cercanos. Los hongos endófitos presentes en estas raíces fueron aislados, cultivados e identificados usando marcadores de ADNr. De un total de 10 especies de orquídeas se obtuvieron 52 aislados. Estos aislamientos se clasificaron en nueve grupos taxonómicos identificados y un grupo de hongos endófitos sin clasificación taxonómica. La mayoría de los grupos taxonómicos aislados estuvieron presentes en no más de dos especies de orquídeas diferentes, no obstante, Coprinellus radians, fue aislado a partir de raíces de todas las orquídeas colectadas. Adicionalmente, en una prueba separada, se evaluó el potencial que tiene C. radians como potenciador de la germinación de semillas de dos orquídeas no presentes en los bosques muestreados. De los dos aislamiento de $C$. radians probados, uno incrementó la germinación de ambas orquídeas a niveles cercanos a la mitad de lo registrado en semillas cultivadas en medio rico en nutrientes (Phytamax), lo cual fue mayor a la nula germinación observada en semillas cultivadas en placas en ausencia del hongo. Nuestros resultados revelan la asociación de hongos del género Coprinellus en todas las orquídeas epífitas estudiadas y un potencial rol para C. radians como promotor de la germinación de semillas de orquídeas.

Key Words / Palabras Clave: Agaricales, Epidendrum, germinación simbiótica, symbiotic germination 
Introduction. Under natural conditions, orchid seeds depend on their interactions with a variety of fungi such as Ceratobasidium spp., Tulasnella spp., Rhizoctonia spp., Epulorhiza spp., and Ceratorhiza spp. to obtain phosphorus, carbon, and nitrogen from the environment to support germination and initial development (Rasmussen 1995, Sathiyadash et al. 2020, Smith \& Read 2010). Understanding these orchid-fungus interactions is key to supporting conservation efforts because orchids produced using alternative propagation methods, such as in vitro culture, show low survival rates after re-introduction into native or rehabilitated habitats and slow growth thereafter (Chen, Wang \& Guo 2012, Herrera et al. 2019, Swarts \& Dixon 2009). Members of Tulasnellaceae and Ceratobasidiaceae are among the most frequently reported mycorrhizal fungi associated with roots of epiphytic orchids (Sathiyadash et al.2020, Suárez et al. 2006), and thus, have received most of the attention in orchid germination studies. However, orchid seed germination in nature likely involves other, and perhaps more complex, interactions with non-mycorrhizal fungi (Meng et al. 2019), and even other types of organisms (Rasmussen et al. 2015). Although the interactions between orchids and nonmycorrhizal microorganisms have been characterized concerning nutrient acquisition, growth stimulation, and pathogen protection processes (Rasmussen et al. 2015, Strobel 2002, Yuan, Chen \& Yang 2009), the role of this group of microorganisms during orchid seed germination remains less understood. The objectives of this study were: 1) to isolate culturable endophytic fungi from roots of ten epiphytic orchids in two montane forests of Southern Ecuador, and 2) to evaluate their possible beneficial role during the germination stage.

\section{Materials and methods}

FUNGAL ENDOPHYTES ASSOCIATED WITH ORCHIDS IN TWO ANDEAN MONTANE FORESTS

Study area and sample collection.- Samples were collected at Mazán and Llaviuco forests, both located in the Macizo del Cajas Biosphere Reserve. Mazán is located $10 \mathrm{~km}$ west of the city of Cuenca in the province of Azuay, Ecuador ( $02^{\circ} 52^{\prime} 12^{\prime \prime}$ S, $\left.79^{\circ} 06^{\prime} 55^{\prime \prime} \mathrm{W}\right)$. The forest covers $\sim 1050$ ha and it is located within the very humid tropical montane forest life zone, according to Holdridge's classification (Holdridge 1987). Air temperature can exceed $20^{\circ} \mathrm{C}$ on sunny days, and it can approach freezing on cold nights. Additionally, precipitation is distributed throughout the year, with lower intensity between July and August. The presence of clouds is frequent, especially in the months of greatest precipitation (February and April). The most abundant vascular plant families in the forest are Asteraceae, Melastomataceae, Solanaceae, Rosaceae and Ericaceae (Minga Ochoa 2000). Orchids are a very diverse group with around 40 species reported within the forest (V. Fleming, unpubl. data 1987). Llaviuco forest is located $17 \mathrm{~km}$ northwest of the city of Cuenca $\left(02^{\circ} 50^{\prime} 40^{\prime \prime} \mathrm{S}, 7^{\circ} 08^{\prime} 33^{\prime \prime} \mathrm{W}\right)$, in a valley next to the Mazán forest. It is very similar to Mazán in most environmental characteristics and its vegetation composition and structure.

In each forest, five study plots were established following the methodology of Gradstein et al. (2003). Briefly, in each plot, a dominant tree was selected and used as a center to delineate a $\sim 500 \mathrm{~m}^{2}$ circular plot with a $12.7 \mathrm{~m}$ radius. Within this plot, orchids were sampled from ground level up to the first branch on all the trees with a diameter at breast height $\geq 10 \mathrm{~cm}$. The sampling stratum was constantly under the shade of the dominant trees, and its air temperature averaged about $10^{\circ} \mathrm{C}$. The canopy at the sampling sites reached $15 \mathrm{~m}$ and the understory was dominated by herbs and young trees. When many specimens of the same orchid were present in a single phorophyte, up to three specimens of each orchid were sampled. Samples, which were only collected from adult orchids, consisted of $5 \mathrm{~cm}$ live root segments containing the root tip. Additionally, fertile specimens and photographs were taken to expert orchid taxonomists for identification.

Root samples were placed in zip-lock bags with their respective identification, transported on ice to the laboratory, and kept refrigerated until processing within $24 \mathrm{~h}$.

Isolation of endophytic fungi.- Endophytic fungi were isolated from root samples as in Zettler, Sharma \& Rasmussen (2003), with some modifications. First, samples were carefully washed with water to avoid damaging the tissue and were then transferred to a 
laminar flow hood to continue the process under sterile conditions. Roots were surface sterilized by immersion in a solution of $4.8 \%$ ethanol and $0.25 \%$ sodium hypochlorite, followed by three rinses in sterile distilled water to remove residues of the disinfectant solution. Clean and intact (no tissues excluded) $2 \mathrm{~cm}$-long root segments were individually transferred to sterile Petri dishes and cut into very small fragments to release hyphae of endophytic fungi. Root fragments were then spread on fungal isolation medium, which was supplemented with $300 \mathrm{mg} \mathrm{L}^{-1}$ streptomycin sulfate to reduce bacterial contamination. The plates were sealed with parafilm and incubated at $27^{\circ} \mathrm{C}$ in the dark. After two days, each hypha that had emerged from root fragments was isolated and subcultured on potato dextrose agar (PDA) on a fresh plate. Isolates were not classified or grouped based on morphological or growth characteristics prior to molecular identification. All cultures were maintained at $27^{\circ} \mathrm{C}$ until processed for molecular analysis.

Identificationofendophyticfungi.-DNAwas extracted from pure fungal cultures using the PureLink Genomic DNA extraction kit (Invitrogen, Carlsbad, CA, USA). DNA integrity was checked by electrophoresis on $1 \%$ agarose gels. Afterwards, a fragment of the ITS region was amplified by nested PCR using primers ITS1 (5'-TCCGTAGGTGAACCTGCGG-3') and TW14 (5'-GCTATCCTGAGGGAAACTTC-3') (Cullings 1994, White et al. 1990) for the first amplification, and then primers ITS1 and NLB4 (5'-GGATTCTCACCCTCTATGAC-3') in the nested reaction (Martin \& Rygiewicz 2005). The amplified fragments were purified and sequenced by an external service provider (Macrogen Inc., South Korea). The sequences were then compared to those deposited in the GenBank databases of NCBI (National Center for Biotechnology Information) using BLAST (Altschul et al. 1997). The identity of each isolate was assigned based on the GenBank accession with the most similar sequence identity.

IN VITRO GERMINATION OF ORCHID SEEDS IN CO-CULTURE WITH COPRINELLUS RADIANS

Species selection and seed quality check- After noticing from initial results that Coprinellus radians was present in all collected roots, we conducted an assay to determine whether this fungus could be involved in the promotion of seed germination. For this test, Epidendrum dalstromii Dodson and E. nocturnum Jacq. were selected. These two orchids had not been present in the study sites in Mazán and Llaviuco forests but were selected due to the availability of their seeds in the University of Cuenca orchid germplasm collection. Epidendrum dalstromii is reported as endemic to Southern Ecuador and is currently listed as an endangered species (León-Yánez et al. 2011). Epidendrum nocturnum is a species widely distributed over the Americas and is currently not listed as threatened in most of its range. Seeds had remained under cold storage for at least one year before the experiment. The viability of each seed lot was evaluated using the tetrazolium test. Briefly, seeds were immersed in a $1 \%$ sodium hypochlorite solution containing one drop of Tween 20 for 15 minutes, and they were then submersed in water for 48 hours in the dark. Seeds were drained and immersed in a $1 \%$ tetrazolium salt solution for 24 hours at $30^{\circ} \mathrm{C}$. Seeds stained after incubation in tetrazolium were considered viable and used for estimating the viability of the seeds. The viability of the E. dalstromii seeds was $90 \%$, whereas it was $20 \%$ for E. nocturnum.

Germination test.- Seeds were surface-sterilized by immersion in $1 \%$ sodium hypochlorite followed by three successive washes in sterile distilled water. Seeds were then resuspended in sterile distilled water to a concentration of $\sim 60$ seeds $/ \mathrm{ml}$ and $500 \mu 1$ of seed suspension were spread on the surface of sterile Petri dishes containing oatmeal-agar. Afterward, a $0.5 \mathrm{~cm}^{2}$ block of PDA containing Coprinellus radians mycelia was placed in the center of each plate. Two C. radians isolates were tested: C. radians 1 and $C$. radians 2 , hereafter. These two isolates showed different morphology although they were classified within the same taxon based on sequencing results. For additional comparisons, seeds were sown on oatmeal agar (a nutrient-poor medium) and Phytamax ${ }^{\mathrm{TM}}$ Orchid Maintenance Medium (Sigma-Aldrich P6668, Saint Louis, MO, USA) (pH 5.6) (a nutrient-rich medium), both without fungus inoculation. Ten replicate plates were prepared for each of the conditions. Plates were incubated at $20^{\circ} \mathrm{C}$ in darkness for 10 days. After this 
period, the plates were incubated for 16 weeks under a 16/8 h light/dark photoperiod. Germination was evaluated at the end of week 16 using the scale of Zettler \& McInnis (1993) where: Stage $0=$ hydrated seeds; Stage $1=$ rupture of the testa due to embryo lengthening; Stage 2 = appearance of rhizoids; Stage 3 = leaf tip emergence; Stage 4 = leaf 0 emergence; and Stage $5=$ leaf blade elongation. The number of seeds in each developmental stage was recorded and compared against counts from uninoculated oatmealagar and Phytamax ${ }^{\mathrm{TM}}$ plates. Seeds were considered to be germinated when rhizoids emerged (Stage 2). The colonization of fungi inside the tissues was not verified. Differences in germination between treatments could not be statistically tested due to the complete absence of germination in the negative control (oatmeal agar), which resulted in statistical test assumptions not satisfied.

\section{Results}

Epiphytic orchid diversity.- A total of 612 orchids were identified within the experimental plots. These orchids were classified within six genera and 10 species, namely: Epidendrum fruticosum Pav. ex Lindl., E. geminiflorum Kunth, Epidendrum sp.1, Epidendrum sp.2, Epidendrum sp.3, Lepanthes sp., Frondaria caulescens (Lind1.) Luer, Pleurothallis coriacardia Rchb.f., Odontoglossum sp. and Stelis sp. The most abundant species was Stelis sp. with 272 specimens. Epidendrum was the most represented genus with five species identified. Each forest showed different orchid diversity indices, whereby Llaviuco generally showed higher diversity than Mazán (Table 1). Specimens of E. fruticosum, E. geminiflorum, $F$. caulescens, and Lepanthes sp. were present only in plots located in the Llaviuco forest.

Endophytic fungal diversity associated with epiphytic orchid roots. - Fifty-two pure isolates were recovered from the orchid roots. These isolates were classified as Coprinellus radians, Trametes sp., Meyerozyma guilliermondii, Penicillium chrysogenum, Penicillium rubens, Fusarium sp., Botryobasidium sp. and Lepidiotaceae (Table 2). An additional isolate was classified at the division level as a mycorrhizal Basidiomycete, and one isolate remained taxonomically unclassified, although its sequence
TABLE 1. Orchid diversity in the sampling plots at Llaviuco and Mazán Forests.

\begin{tabular}{lccc}
\hline & Llaviuco & Mazán & Both forests \\
\hline Specimens & & & \\
\hline Stelis sp. & 211 & 61 & 272 \\
\hline Epidendrum sp1 & 64 & 4 & 68 \\
\hline Epidendrum sp2 & 23 & 4 & 27 \\
\hline Epidendrum sp3 & 114 & 18 & 132 \\
\hline Epidendrum geminiflorum & 14 & 0 & 14 \\
\hline Frondaria caulescens & 1 & 0 & 1 \\
\hline Lephante sp. & 4 & 0 & 4 \\
\hline Odontoglossum sp. & 17 & 18 & 35 \\
\hline Pleurothallis coriacardia & 11 & 1 & 12 \\
\hline Epidendrum fruticosum & 47 & 0 & 47 \\
\hline Total & 506 & 106 & 612 \\
\hline & & & \\
\hline Species richness & 10 & 6 & 10 \\
\hline Shannon's H' $^{\prime}$ & 1.67 & 1.21 & 1.64 \\
\hline
\end{tabular}

has been reported to belong to an endophytic fungus colonizing purple loosestrife (Lythrum salicaria) (David et al. 2016). Forty-one of the 52 isolates were classified as $C$. radians, making this species the most abundant in orchid roots from both forests; all other species were represented by only one or two isolates each. Coprinellus radians, Trametes sp., and $P$. chrysogenum were isolated from both forests, whereas the other fungi were found exclusively in either the Mazán or Llaviuco forest.

When analyzing how the diversity of endophytes was distributed across the diversity of orchids, no more than three different endophytic fungi were associated to the same orchid species (Fig. 1). In the case of Pleurothallis coriacardia and Lepanthes sp., only one endophyte was associated with their roots. Most fungal endophyte isolates (six out of 10) were recovered from the roots of only one orchid species, although three endophytes were isolated from two different orchid species. Most notably, Coprinellus radians was isolated from all orchid species sampled (Fig. 1 and Table 3).

Germination-promoting effects of Coprinellus radians.-Due to the presence of the fungal species $C$. radians in all sampled orchid species, a germination test was carried out with two different isolates belonging to this fungus (C. radians 1 and $C$. radians 2). Only isolate $C$. radians 2 promoted germination of both 
TABLE 2. Identification of ITS sequences of endophytic fungi isolates from orchid roots in Mazán and Llaviuco forests.

\begin{tabular}{|c|c|c|c|c|}
\hline Isolate & Max identity (\%) & $\begin{array}{c}\text { Assigned identity based on most } \\
\text { similar GenBank accession }\end{array}$ & GenBank accession & Source \\
\hline UC-2II & $96 \%$ & Coprinellus radians & FJ185160 & Badalyan et al. (2011) \\
\hline UC-4II & $99 \%$ & Fungal endophyte & KT291127 & David et al. (2016) \\
\hline UC-5II & $99 \%$ & Coprinellus radians & FJ185160 & Badalyan et al. (2011) \\
\hline UC-6II & $99 \%$ & Coprinellus radians & FJ185160 & Badalyan et al. (2011) \\
\hline UC-7II & $85 \%$ & Fungal endophyte & KT291127 & David et al. (2016) \\
\hline UC-8II & $98 \%$ & Coprinellus radians & FJ185160 & Badalyan et al. (2011) \\
\hline UC-12II & $98 \%$ & Coprinellus radians & FJ185160 & Badalyan et al. (2011) \\
\hline UC-13II & $98 \%$ & Coprinellus radians & FJ185160 & Badalyan et al. (2011) \\
\hline UC-15II & $99 \%$ & Coprinellus radians & FJ185160 & Badalyan et al. (2011) \\
\hline UC-16II & $98 \%$ & Coprinellus radians & FJ185160 & Badalyan et al. (2011) \\
\hline UC-17II & $98 \%$ & Coprinellus radians & FJ185160 & Badalyan et al. (2011) \\
\hline UC-18\|I & $98 \%$ & Coprinellus radians & FJ185160 & Badalyan et al. (2011) \\
\hline UC-19II & $98 \%$ & Coprinellus radians & FJ185160 & Badalyan et al. (2011) \\
\hline UC-20II & $89 \%$ & Penicillium chrysogenum & JF834167 & Guo et al. (Unpub. data) \\
\hline UC-23M & $98 \%$ & Coprinellus radians & FJ185160 & Badalyan et al. (2011) \\
\hline UC-24M & $99 \%$ & Coprinellus radians & FJ185160 & Badalyan et al. (2011) \\
\hline UC-25M & $99 \%$ & Coprinellus radians & FJ185160 & Badalyan et al. (2011) \\
\hline UC-26M & $98 \%$ & Coprinellus radians & FJ185160 & Badalyan et al. (2011) \\
\hline UC-27M & $99 \%$ & Coprinellus radians & FJ185160 & Badalyan et al. (2011) \\
\hline UC-28M & $99 \%$ & Trametes sp. & KJ831923 & Gazis et al. (Unpub. data) \\
\hline UC-29M & $98 \%$ & Coprinellus radians & FJ185160 & Badalyan et al. (2011) \\
\hline UC-30M & $99 \%$ & Fusarium sp. & KU974301 & Moretti et al. (2011) \\
\hline UC-31M & $98 \%$ & Coprinellus radians & FJ185160 & Badalyan et al. (2011) \\
\hline UC-32II & $98 \%$ & Coprinellus radians & FJ185160 & Badalyan et al. (2011) \\
\hline UC-34II & $98 \%$ & Penicillium rubens & LT558978 & $\begin{array}{l}\text { Guevara Suarez et al. } \\
\qquad(2016)\end{array}$ \\
\hline UC-35II & $98 \%$ & Coprinellus radians & FJ185160 & Badalyan et al. (2011) \\
\hline UC-36II & $99 \%$ & Meyerozyma guilliermondii & KJ451706 & Herkert (Unpub. data) \\
\hline UC-37II & $99 \%$ & Coprinellus radians & FJ185160 & Badalyan et al. (2011) \\
\hline UC-40II & $96 \%$ & Coprinellus radians & FJ185160 & Badalyan et al. (2011) \\
\hline UC-42II & $99 \%$ & Coprinellus radians & FJ185160 & Badalyan et al. (2011) \\
\hline UC-43॥ & $99 \%$ & Coprinellus radians & FJ185160 & Badalyan et al. (2011) \\
\hline UC-47II & $99 \%$ & Coprinellus radians & FJ185160 & Badalyan et al. (2011) \\
\hline UC-53II & $89 \%$ & Trametes sp. & KF578082 & Maza et al. (2014) \\
\hline UC-55II & $99 \%$ & Coprinellus radians & FJ185160 & Badalyan et al. (2011) \\
\hline UC-56II & $98 \%$ & Coprinellus radians & FJ185160 & Badalyan et al. (2011) \\
\hline UC-59II & $99 \%$ & Coprinellus radians & FJ185160 & Badalyan et al. (2011) \\
\hline UC-60II & $94 \%$ & Mycorrhizal Basidiomycete & $\mathrm{AB} 176570$ & Yamato et al. (2005) \\
\hline UC-61II & $98 \%$ & Coprinellus radians & FJ185160 & Badalyan et al. (2011) \\
\hline UC-63M & $98 \%$ & Coprinellus radians & FJ185160 & Badalyan et al. (2011) \\
\hline UC-64M & $97 \%$ & Botryobasidium sp. & KU194318 & Ding \& Gu (Unpub. data) \\
\hline UC-65M & $99 \%$ & Penicillium chrysogenum & KF011475 & Wicklow (2013) \\
\hline
\end{tabular}


TABLE 2 continues

\begin{tabular}{lllll}
\hline UC-66M & $98 \%$ & Coprinellus radians & FJ185160 & Badalyan et al. (2011) \\
\hline UC-68M & $98 \%$ & Coprinellus radians & FJ185160 & Badalyan et al. (2011) \\
\hline UC-69M & $99 \%$ & Coprinellus radians & FJ185160 & Badalyan et al. (2011) \\
\hline UC-70M & $98 \%$ & Coprinellus radians & FJ185160 & Badalyan et al. (2011) \\
\hline UC-75M & $98 \%$ & Coprinellus radians & FJ185160 & Badalyan et al. (2011) \\
\hline UC-76M & $98 \%$ & Coprinellus radians & FJ185160 & Badalyan et al. (2011) \\
\hline UC-77M & $75 \%$ & Lepidiotaceae & AF079745 & Mueller et al. (1998) \\
\hline UC-78M & $98 \%$ & Coprinellus radians & FJ185160 & Badalyan et al. (2011) \\
\hline UC-80M & $98 \%$ & Coprinellus radians & FJ185160 & Badalyan et al. (2011) \\
\hline UC-81M & $98 \%$ & Coprinellus radians & FJ185160 & Badalyan et al. (2011) \\
\hline UC-83M & $99 \%$ & Penicillium chrysogenum & KF011475 & Wicklow (2013) \\
\hline
\end{tabular}

Epidendrum dalstromii and E. nocturnum seeds (Table 4). The germination rate in co-culture with $C$. radians 2 was low in absolute terms $(2.9 \%$ and $13.3 \%$ for $E$. nocturnum and $E$. dalstromii, respectively); however, no seeds germinated in the plates containing oatmeal agar without fungi, indicating germination promoting effect of this fungus. Nonetheless, this germination promoting effect was not as strong as the one observed in nutrient-rich Phytamax ${ }^{\mathrm{TM}}(7.3 \%$ and $24.4 \%$ for $E$. nocturnum and $E$. dalstromii, respectively).

\section{Discussion}

Fungi and orchids form both specialist and generalist relationships. These relationships often arise from specific ecological roles, although in many cases these roles have not yet been elucidated ( FavreGodal et al. 2020, Selosse 2014). The genera of six of the 10 fungal endophytes identified in our study have been previously reported as orchid endophytes; two of them have also been reported to form mycorrhizal

\section{ORCHIDS}

\section{FUNGI}

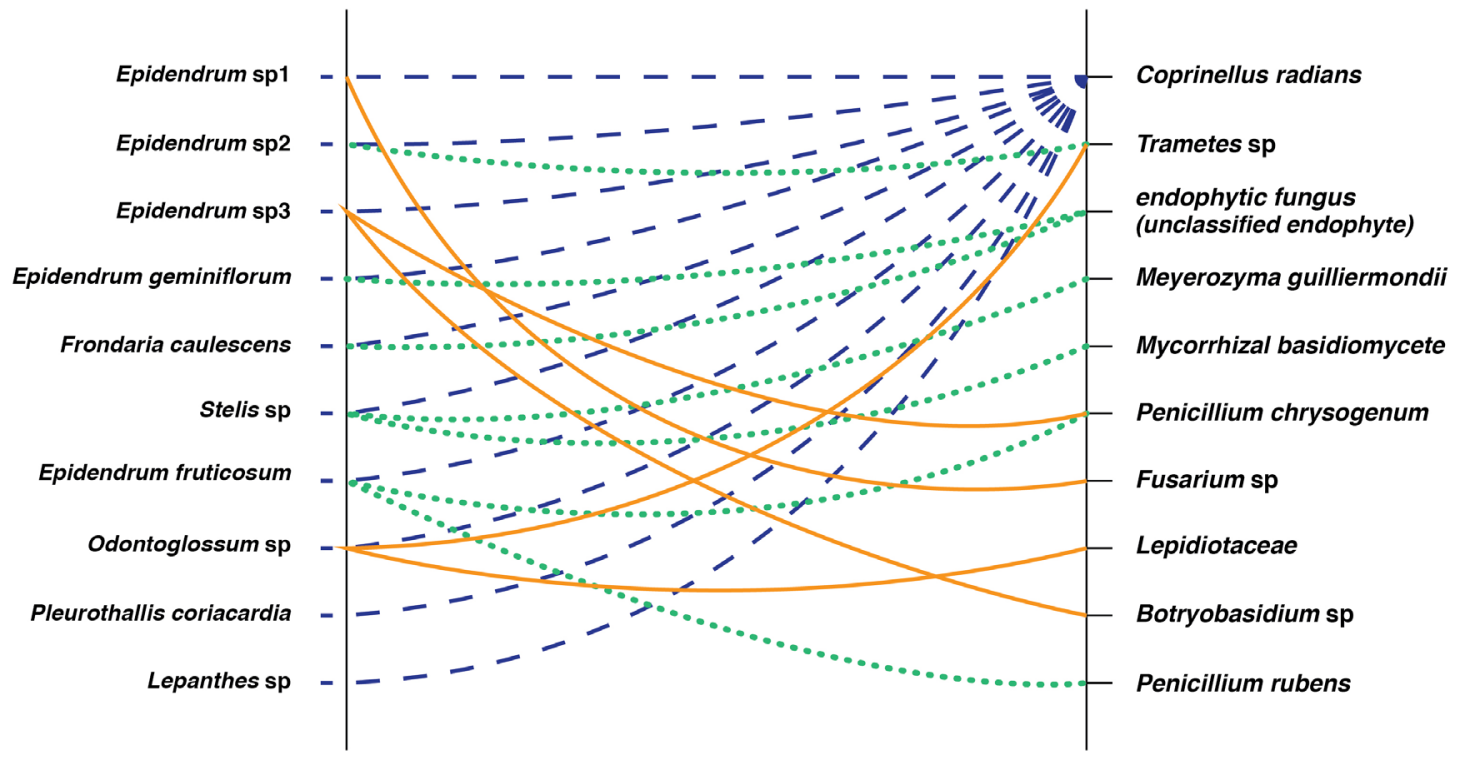

FIGURE 1. Endophytic fungal diversity associated with epiphytic orchid roots in two Andean montane forests. Solid, dotted, or dashed lines represent isolates from orchids present at Mazán, Llaviuco, or both forests, respectively. 
TABLE 3. Endophytic fungal diversity associated with roots of orchids from the sampling sites at Llaviuco and Mazán Forests.

\begin{tabular}{|c|c|c|c|c|c|c|c|c|c|c|}
\hline \multicolumn{11}{|c|}{ Orchid host } \\
\hline Putative isolate identity & $\begin{array}{l}\frac{\dot{0}}{0} \\
\frac{0}{0} \\
\frac{0}{\infty}\end{array}$ & $\begin{array}{l}\frac{5}{0} \\
\text { के } \\
\frac{5}{3} \\
\frac{2}{0} \\
\frac{0}{0} \\
\frac{0}{2}\end{array}$ & $\begin{array}{l}\text { N } \\
\text { क } \\
5 \\
5 \\
\frac{5}{0} \\
\frac{1}{d} \\
\frac{0}{2} \\
\text { Uి }\end{array}$ & $\begin{array}{l}\text { m } \\
\text { on } \\
5 \\
5 \\
\frac{5}{0} \\
\frac{8}{8} \\
\frac{0}{0} \\
\text { Uి }\end{array}$ & 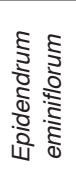 & 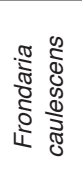 & 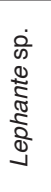 & 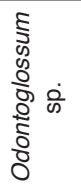 & 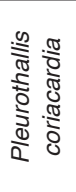 & 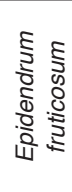 \\
\hline Coprinellus radians & 7 & 3 & 1 & 10 & 1 & 1 & 1 & 7 & 2 & 6 \\
\hline Endophytic fungus & - & - & - & - & 1 & 1 & - & - & - & - \\
\hline Meyerozyma guilliermondii & 1 & - & - & - & - & - & - & - & - & - \\
\hline Mycorrhizal Basidiomycete & 1 & - & - & - & - & - & - & - & - & - \\
\hline Penicillium chrysogenum & - & - & - & - & - & - & - & - & - & 1 \\
\hline Trametes sp. & - & - & 1 & - & - & - & - & 1 & - & - \\
\hline Fusarium sp. & - & 1 & - & - & - & - & - & - & - & - \\
\hline Penicillium rubens & - & - & - & - & - & - & - & - & - & 1 \\
\hline Botryobasidium sp. & - & - & - & 1 & - & - & - & - & - & - \\
\hline Penicillium chrysogenum & - & - & - & 2 & - & - & - & - & - & - \\
\hline Lepidiotaceae & - & - & - & - & - & - & - & 1 & - & - \\
\hline Total number of isolates per orchid species & 9 & 4 & 2 & 13 & 2 & 2 & 1 & 9 & 2 & 8 \\
\hline Fungal isolate richness per orchid species & 3 & 2 & 2 & 3 & 2 & 2 & 1 & 3 & 1 & 3 \\
\hline Shannon's H' & 0.68 & 0.56 & 0.69 & 0.68 & 0.69 & 0.69 & 0 & 0.68 & 0 & 0.73 \\
\hline
\end{tabular}

TABLE 4. Number of seeds germinated in co-cultures of Epidendrum nocturnum and Epidendrum dalstromii seeds with two Coprinellus radians isolates on oatmeal-agar (OA) after 122 days ( $\mathrm{n}=10$ plates). Seeds germinated on $\mathrm{Phytamax}^{\mathrm{TM}}$ medium (P) were included for comparison of the responses from nutrient rich medium.

\begin{tabular}{c|ccccccc}
\hline \multirow{2}{*}{ Orchid } & $\begin{array}{c}\text { Germination } \\
\text { conditions }\end{array}$ & $\begin{array}{c}\text { Seeds sown } \\
\text { per plate }\end{array}$ & a Unchanged & Stage 0 & Stage 1 & Stage 2 & Germinated (\%) \\
\hline \multirow{4}{*}{$\begin{array}{c}\text { Epidendrum } \\
\text { nocturnum }\end{array}$} & $\mathrm{OA}+$ C. radians 1 & $26.3 \pm 4.01$ & $19.7 \pm 3.63$ & $6.5 \pm 0.71$ & $0.1 \pm 0.1$ & $0.0 \pm 0.0$ & $0.0 \pm 0.0$ \\
\cline { 2 - 8 } & $\mathrm{OA}+$ C. radians 2 & $34.2 \pm 6.21$ & $26.0 \pm 5.7$ & $3.4 \pm 0.22$ & $3.8 \pm 0.35$ & $1.0 \pm 0.14$ & $3.32 \pm 0.1$ \\
\cline { 2 - 8 } & Negative (OA) & $27.0 \pm 7.36$ & $18.4 \pm 2.22$ & $8.4 \pm 0.45$ & $0.2 \pm 0.20$ & $0.0 \pm 0.0$ & $0.0 \pm 0.0$ \\
\cline { 2 - 8 } & Positive (P) & $35.6 \pm 5.21$ & $27.1 \pm 4.64$ & $1.0 \pm 0.29$ & $4.9 \pm 0.45$ & $2.6 \pm 0.54$ & $7.06 \pm 0.65$ \\
\hline \multirow{4}{*}{$\begin{array}{c}\text { Epidendrum } \\
\text { dalstromii }\end{array}$} & $\mathrm{OA}+$ C. radians 1 & $27.4 \pm 2.17$ & $4.2 \pm 0.85$ & $22.3 \pm 1.59$ & $0.9 \pm 0.23$ & $0.0 \pm 0.0$ & $0.0 \pm 0.0$ \\
\cline { 2 - 8 } & $\mathrm{OA}+$ C. radians 2 & $32.3 \pm 1.74$ & $4.2 \pm 0.64$ & $13.6 \pm 1.09$ & $10.2 \pm 0.87$ & $4.3 \pm 0.49$ & $13.46 \pm 1.66$ \\
\cline { 2 - 8 } & Negative (OA) & $31.1 \pm 1.08$ & $5.9 \pm 0.62$ & $25.2 \pm 1.21$ & $0.0 \pm 0.0$ & $0.0 \pm 0.0$ & $0.0 \pm 0.0$ \\
\cline { 2 - 8 } & Positive (P) & $31.2 \pm 2.05$ & $4.5 \pm 1.08$ & $2.2 \pm 0.24$ & $16.9 \pm 1.79$ & $7.6 \pm 1.15$ & $24.39 \pm 3.22$ \\
\hline
\end{tabular}

a Germination stages: Unchanged $=$ the seed has not changed from its original state at sowing; Stage 0 = hydrated seeds; Stage $1=$ rupture of the testa due to embryo lengthening; Stage 2 = appearance of rhizoids

associations with orchids (Yamato et al. 2005, Yukawa et al. 2009). For instance, Penicillium spp. (Bayman et al. 1997, Tremblay 2008, Yuan et al. 2009, Sudheep \& Sridhar 2012) and Fusarium spp. (Bayman et al. 1997, Behera, Tayung \& Mohapatra 2013, Jiang et al. 2019, Yuan et al. 2009) have been isolated from the roots of epiphytic orchids and have demonstrated growth-promoting effects on their hosts (Jiang et al.
2019, Ovando et al. 2005). Likewise, similar effects have been reported for Meyerozyma sp. (Pecoraro et al. 2012), Botryobasidium sp. (Ogura-Tsujita et al. 2012), and Trametes sp. (Cueva 2014). Most studies on the relationships between orchids and endophytic fungi have focused on the potential role of the latter in pathogen defense, improved nutrient acquisition, or stress tolerance (Ordoñez Castillo 2012, Yuan et al. 
2009), with other potential ecological roles remaining mostly unexplored. Although less frequently studied, the germination enhancing the effects of endophytic and saprophytic fungi, such as Fusarium spp. or Mycena spp., have also been reported (Meng et al. 2019). In this study, most of the isolated endophytes were associated with a limited number of orchid species, suggesting potential specific interactions between these endophytes and their hosts. However, the isolation of Coprinellus radians from the roots of all sampled orchids represented a striking exception and suggested a wide generalist relationship between this fungus and orchids.

Associations between orchids and members of Psathyrellaceae, to which Coprinellus spp. belong, have been reported as beneficial to orchid growth and development (Terashita \& Chuman 1987, Yagame et al. 2013, Yamato et al. 2005, Yukawa et al. 2009). Furthermore, Coprinellus spp. have been reported to promote germination in the terrestrial orchid Epipogium roseum and increase the growth of its rhizomes and tubers (Yagame et al. 2007, Yagame et al. 2008). Xiaoya and collaborators (2015) have confirmed that Coprinellus spp. establish generalist mycorrhizal associations with terrestrial orchids beginning at the seed stage. Here, we found $C$. radians associated with the roots of all orchids sampled, supporting the findings of Xiaoya et al. (2015) that this fungus can establish generalistic relationships with diverse orchid species. Further, we confirmed the potential role of $C$. radians in promoting germination in two epiphytic orchids, although only one of the tested fungal isolates showed this effect. While the association of $C$. radians to terrestrial orchids is not new (Terashita \& Chuman 1987, Yagame et al. 2013, Yamato et al. 2005, Yukawa et al. 2009), our results report for the first time the association of $C$. radians to epiphytic orchids and reveal a potential ecological role for this endophyte. Saprophytic members of Coprinaceae have been reported as potential intermediary providers of organic carbon from decaying wood to the mycothropic orchid Epipogium roseum (Sathiyadash et al. 2020). Carbon remobilized by fungi from decaying substrates could serve as energy source for germinating orchid seeds and favor the establishment of orchid-endophyte associations. Such interactions between orchids, saprophytic fungi, and decaying substrates have also been suggested for Epidendrum spp. in the same forests studied by us (Herrera et al. 2019). Considering the large diversity of orchids present in tropical montane forests, describing and characterizing the interactions between orchids and their endophytes is relevant for a better understanding of the ecology of these plants and the ecosystems in which they grow. In this study, we described a small portion of the endophytic fungal community and explored a potential ecological role for one of the endophytes. However, investigating the more complex interactions that also exist, such as with other endophytes (e.g., bacteria) and the phorophytes that support epiphytic orchids, could contribute to a more thorough description of orchid ecology. Here, we found a widespread association between $C$. radians and all the orchids studied, which demonstrates a generalistic association of this fungus with the orchid community in the Tropical Montane forests used for this study. In contrast, the presence of all the other isolates was restricted mainly to only one orchid species which could suggest a more specific type of interaction between these fungi and their orchid hosts. Nonetheless, this study was not designed to test for specialistic relationships and cannot conclude on this point based on our data.

Our data suggest that Coprinellus radians could be an important component of the endophytic community of epiphytic orchids in the Andean montane forests. In addition, our data showed that at least one of these $C$. radians isolates promotes orchid seed germination. Together, our results contribute to scientific understanding of the relationships between orchids and their associated organisms and how these interactions can be used to design effective conservation strategies in the future.

ACKNOWLEDGEMENTS. This project was funded by internal competitive funds from the University of Cuenca through project "Relaciones inter-específicas entre hospederos, orquídeas epífitas y microorganismos fitoestimulantes asociados a sus raíces, en bosques nativos andinos de la provincia del Azuay" under research permit 121-2016DPAA/MA and Genetic Resource Access contract MAEDNB-CM-2018-0084 granted by the National Biodiversity Direction of the Ecuadorian Ministry of the Environment. 


\section{LITERATURE CITED}

Altschul, S., Madden, T. L., Schäffer, A. A., Zhang, J., Zhang, Z., Miller, W. \& Lipman, D. J. (1997). Gapped BLAST and PSI-BLAST: a new generation of protein database search programs. Nucleic Acids Research, 25(17), 3389-3402. DOI: https://doi.org/10.1093/nar/25.17.3389

Badalyan, S. M., Szafranski, K., Hoegger, P. J., Navarro-González, M., Majcherczyk, A. \& Kües, U. (2011). New Armenian wood-associated coprinoid mushrooms: Coprinopsis strossmayeri and Coprinellus aff. radians. Diversity, 3(1), 136-154. DOI: 10.3390/d3010136

Bayman, P., Lebron, L. L., Tremblay, R. L. \& Lodge, D. J. (1997). Variation in endophytic fungi from roots and leaves of Lepanthes (Orchidaceae). New Phytologist, 135(1), 143-149. DOI: https://doi.org/10.1046/j.1469-8137.1997.00618.x

Behera, D., Tayung, K. \& Mohapatra, U. B. (2013). PCR-based identification of endophytes from three orchid species collected from Similipal Biosphere Reserve, India. American International Journal of Research in Formal, Applied and Natural Sciences, 3, 10-17.

Chen, J., Wang, H. \& Guo, S.-X. (2012). Isolation and identification of endophytic and mycorrhizal fungi from seeds and roots of Dendrobium (Orchidaceae). Mycorrhiza, 22(4), 297-307. DOI: https://doi.org/10.1007/s00572-011-0404-0

Cueva, A. (2014). Caracterización molecular de hongos micorrízicos aislados a partir de cuatro especies de orquídeas epífitas, en dos pisos altitudinales de bosque montano. Loja, Ecuador: Universidad Técnica Particular de Loja.

Cullings, K. W. (1994). Molecular phylogeny of the Monotropoideae (Ericaceae) with a note on the placement of the Pyroloideae. Journal of Evolutionary Biology, 7, 501-516. DOI: https://doi.org/10.1046/j.1420-9101.1994.7040501.x

David, A. S., Quiram, G. L., Sirota, J. I. \& Seabloom, E. W. (2016). Quantifying the associations between fungal endophytes and biocontrol-induced herbivory of invasive purple loosestrife (Lythrum salicaria L.). Mycologia, 108(4), 625-637.

Favre-Godal, Q., Gourguillon, L., Lordel-Madeleine, S., Gindro, K. \& Choisy, P. (2020). Orchids and their mycorrhizal fungi: an insufficiently explored relationship. Planta Medica, 85(18), 1445. DOI: https://doi.org/10.1055/s-0039-3399784

Fleming, V. (1987). Plans: Botanical work (Principally on orchids and other flowering plants) at the Río Mazán montane rain forest reserve Ecuador. In: D. McLean \& M. Hancock (Eds.), Cuenca: Río Mazán Project. Technical Report, Unpublished.

Gradstein, S. R., Nadkarni, N. M., Krömer, T., Holz, I. \& Nöske, N. (2003). A protocol for rapid and representative sampling of vascular and non-vascular epiphyte diversity of tropical rain forests. Selbyana, 24, 105-111. DOI: https://doi. org/10.2307/41750962

Guevara-Suarez, M., Sutton, D. A., Cano-Lira, J. F., García, D., Martin-Vicente, A., Wiederhold, N., Guarro, J. \& Gené, J. (2016). Penicillium-like fungi from clinical samples in the USA and their antifungal susceptibility. Journal of Clinical Microbiology, 54, 2155-2161. DOI: 10.1128/JCM.00960-16.

Herrera, H., García-Romera, I., Meneses, C., Pereira, G. \& Arriagada, C. (2019). Orchid mycorrhizal interactions on the Pacific side of the Andes from Chile. A review. Journal of Soil Science and Plant Nutrition, 19(1), 187-202. DOI: https://doi. org/10.1007/s42729-019-00026-X

Herrera, P., Suárez, J. P., Sánchez-Rodríguez, A., Molina, M. C., Prieto, M. \& Méndez, M. (2019). Many broadly-shared mycobionts characterize mycorrhizal interactions of two coexisting epiphytic orchids in a high elevation tropical forest. Fungal Ecology, 39, 26-36. DOI: https://doi.org/10.1016/j.funeco.2018.11.003

Holdridge, L. R. (1987). Ecología basada en zonas de vida (No. 83). San José, Costa Rica: Instituto Interamericano de Ciencias Agrícolas.

Jiang, J., Zhang, K., Cheng, S., Nie, Q., Zhou, S. X., Chen, Q., Zhou, J., Zhen, X., Li, X. T., Zhen, T. W., Xu, M., Hsiang, T., Sun, Z. \& Zhou, Y. (2019). Fusarium oxysporum KB-3 from Bletilla striata: an orchid mycorrhizal fungus. Mycorrhiza, 29(5), 531-540. DOI: https://doi.org/10.1007/s00572-019-00904-3

León-Yánez, S., Valencia, R., Pitman, N., Endara, L., Ulloa Ulloa, C. \& Navarrete, H. (2011). Libro rojo de plantas del Ecuador. Retrieved from https://bioweb.bio/floraweb/librorojo/FichaEspecie/Epidendrum\%20dalstromii [Accesed on April 15, 2019].

Martin, K. J. \& Rygiewicz, P. T. (2005). Fungal-specific PCR primers developed for analysis of the ITS region of environmental DNA extracts. BMC Microbiology, 5, 28. DOI: https://doi.org/10.1186/1471-2180-5-28

Maza, M., Pajot, H. F., Amoroso, M. J. \& Yasem, M. G. (2014). Post-harvest sugarcane residue degradation by autochthonous fungi. International Biodeterioration \& Biodegradation, 87, 18-25. DOI: https://doi.org/10.1016/j. ibiod.2013.10.020

Meng, Y. Y., Zhang, W. L., Selosse, M. A. \& Gao, J. Y. (2019). Are fungi from adult orchid roots the best symbionts at germination? A case study. Mycorrhiza, 29(5), 541-547. DOI: https://doi.org/10.1007/s00572-019-00907-0

Minga Ochoa, D. (2000). Árboles y arbustos del bosque de Mazán (pp. 2, 8-9). Cuenca, Ecuador: Empresa Pública Municipal de Telecomunicaciones, Agua Potable y Alcantarillado. 
Mueller, U. G., Rehner, S. A. \& Schultz, T. R. (1998). The evolution of agriculture in ants. Science, 281(5385), $2034-$ 2038. DOI: $10.1126 /$ science.281.5385.2034

Ogura-Tsujita, Y., Yokoyama, J., Miyoshi, K. \& Yukawa, T. (2012). Shifts in mycorrhizal fungi during the evolution of autotrophy to mycoheterotrophy in Cymbidium (Orchidaceae). American Journal of Botany, 99(7), 1158-1176. DOI: https://doi.org/10.3732/ajb.1100464

Ordoñez Castillo, N. F. (2012). Efecto de hongos endófitos de orquídeas del grupo Rhizoctonia y otros endófitos cultivables sobre el desarrollo de plantas de Vanilla planifolia Jacks. Universidad Nacional de Colombia. Retrieved from https://oatd. org/oatd/record?record=oai\%5C \%3Awww.bdigital.unal.edu.co\%5C $\% 3 \mathrm{~A} 6760$

Ovando, I., Damon, A., Bello, R., Ambrosio, D., Albores, V., Adriano, L. \& Salvador, M. (2005). Isolation of endophytic fungi and their mycorrhizal potential for the tropical epiphytic orchids Cattleya skinneri, C. aurantiaca and Brassavola nodosa. Asian Journal of Plant Sciences, 4, 309-315. DOI: http://docsdrive.com/pdfs/ansinet/ajps/2005/309-315.pdf

Pecoraro, L., Girlanda, M., Kull, T., Perini, C. \& Perotto, S. (2012). Analysis of fungal diversity in Orchis tridentata Scopoli. Open Life Sciences, 7(5), 850-857. DOI: https://doi.org/10.2478/s11535-012-0071-y

Rasmussen, H. N. (1995). Terrestrial orchids: from seed to mycotrophic plant. Cambridge, U.K.: Cambridge University Press.

Rasmussen, H. N., Dixon, K. W., Jersáková, J. \& Těšitelová, T. (2015). Germination and seedling establishment in orchids: a complex of requirements. Annals of Botany, 116(3), 391-402. DOI: https://doi.org/10.1093/aob/mcv087

Sathiyadash, K., Muthukumar, T., Karthikeyan, V. \& Rajendran, K. (2020). Orchid mycorrhizal fungi: structure, function, and diversity. In: S. M. Khasim, S. N. Hegde, M. T. González-Arnao \& K. Thammasiri (Eds.), Orchid biology: recent trends \& challenges (pp. 239-280). Singapore: Springer.

Selosse, M.-A. (2014). The latest news from biological interactions in orchids: in love, head to toe. New Phytologist, 202(2), 337-340. DOI: https://doi.org/10.1111/nph.12769

Smith, S. E. \& Read, D. J. (2010). Mycorrhizal symbiosis. Cambridge, U.K.: Academic Press.

Strobel, G. A. (2002). Rainforest endophytes and bioactive products. Critical Reviews in Biotechnology, 22(4), 315-333. DOI: https://doi.org/10.1080/07388550290789531

Suárez, J. P., Weiss, M., Abele, A., Garnica, S., Oberwinkler, F. \& Kottke, I. (2006). Diverse tulasnelloid fungi form mycorrhizas with epiphytic orchids in an Andean cloud forest. Mycological Research, 110(11), 1257-1270. DOI: https:// doi.org/10.1016/j.mycres.2006.08.004

Sudheep, N. M. \& Sridhar, K. R. (2012). Non-mycorrhizal fungal endophytes in two orchids of Kaiga forest (Western Ghats), India. Journal of Forestry Research, 23(3), 453-460. DOI: https://doi.org/10.1007/s11676-012-0284-y

Swarts, N. D. \& Dixon, K. W. (2009). Terrestrial orchid conservation in the age of extinction. Annals of Botany, 104(3), 543-556. DOI: https://doi.org/10.1093/aob/mcp025

Terashita, T. \& Chuman, S. (1987). Fungi inhabiting wild orchids in Japan (IV). Armillariella tabescens, a new symbiont of Galeola septentrionales. Transactions of the Mycological Society of Japan, 28(2), 145-154. Retrieved from https://www. cabdirect.org/cabdirect/abstract/19881343652

Tremblay, R. L. (2008). Ecological correlates and short-term effects of relocation of a rare epiphytic orchid after Hurricane Georges. Endangered Species Research, 5(1), 83-90. DOI: https://doi.org/10.3354/esr00114

White, T. J., Bruns, T., Lee, S. J. W. T. \& Taylor, J. W. (1990). Amplification and direct sequencing of fungal ribosomal RNA genes for phylogenetics. In: M. A. Innis, D. H. Gelfand, J. J. Sninsky \& T. J. White (Eds.), PCR protocols: a guide to methods and applications (pp. 315-322). New York: Academic Press.

Xiaoya, M., Kang, J., Nontachaiyapoom, S., Wen, T. \& Hyde, K. D. (2015). Non-mycorrhizal endophytic fungi from orchids. Current Science, 108, 1-16. DOI: http://www.jstor.org/stable/24905693

Yagame, T., Fukiharu, T., Yamato, M., Suzuki, A. \& Iwase, K. (2008). Identification of a mycorrhizal fungus in Epipogium roseum (Orchidaceae) from morphological characteristics of basidiomata. Mycoscience, 49(2), 147-151. DOI: https://doi. org/10.1007/s10267-007-0396-y

Yagame, T., Funabiki, E., Nagasawa, E., Fukiharu, T. \& Iwase, K. (2013). Identification and symbiotic ability of Psathyrellaceae fungi isolated from a photosynthetic orchid, Cremastra appendiculata (Orchidaceae). American Journal of Botany, 100(9), 1823-1830. DOI: https://doi.org/10.3732/ajb.1300099

Yagame, T., Yamato, M., Mii, M., Suzuki, A. \& Iwase, K. (2007). Developmental processes of achlorophyllous orchid, Epipogium roseum: From seed germination to flowering under symbiotic cultivation with mycorrhizal fungus. Journal of Plant Research, 120(2), 229-236. DOI: https://doi.org/10.1007/s10265-006-0044-1

Yamato, M., Yagame, T., Suzuki, A. \& Iwase, K. (2005). Isolation and identification of mycorrhizal fungi associating with an achlorophyllous plant, Epipogium roseum (Orchidaceae). Mycoscience, 46(2), 73-77. DOI: https://doi.org/10.1007/ s10267-004-0218-4 
Yuan, Z., Chen, Y. \& Yang, Y. (2009). Diverse non-mycorrhizal fungal endophytes inhabiting an epiphytic, medicinal orchid (Dendrobium nobile): estimation and characterization. World Journal of Microbiology and Biotechnology, 25(2), 295-303. DOI: https://doi.org/10.1007/s11274-008-9893-1

Yukawa, T., Ogura-Tsujita, Y., Shefferson, R. P. \& Yokoyama, J. (2009). Mycorrhizal diversity in Apostasia (Orchidaceae) indicates the origin and evolution of orchid mycorrhiza. American Journal of Botany, 96(11), 1997-2009. DOI: https:// doi.org/10.3732/ajb.0900101

Zettler, L. W. \& McInnis Jr., T. M. (1993). Symbiotic seed germination and development of Spiranthes cernua and Goodyera pubescens (Orchidaceae: Spiranthoideae). Lindleyana, 8(3), 155-162.

Zettler, L. W., Sharma, J. \& Rasmussen, F. P. N. (2003). Mycorrhizal diversity. In: K. W. Dixon, S. P. Kell, R. L. Barrett \& P. J. Cribb (Eds.), Orchid conservation (pp. 205-226). Kota Kinabalu, Sabah, Malaysia: Natural History Publications. 
